\title{
Culture in Contrastive Lexicographical Prospects
}

\author{
Olga Ivanishcheva ${ }^{1}$ \\ ${ }^{1}$ Murmansk, Russia \\ Correspondence: Olga Ivanishcheva, Murmansk, Russia. E-mail: oivanishcheva@gmail.com
}

Received: November 19, 2013

Accepted: December 16, 2013

Online Published: December 18, 2013

doi:10.5430/elr.v2n2p155

URL: http://dx.doi.org/10.5430/elr.v2n2p155

\begin{abstract}
The present paper reports on the problems of culture elements representation in a bilingual dictionary. It is proved that cultural information on a realia is necessary for a dictionary definition. Taking into account cultural value of a feature the following elements of a realia description should be present in a bilingual dictionary: a) attributes (appearance, components, traditions); b) estimation; c) historical markedness (time of usage, actions); d) social status (functions); e) function (purpose, role); f) popularity / unpopularity of a realia; g) symbolic meaning. The article emphasizes the importance to represent the culture of the indigenous people. Certain comments will depend on the proximity of cultures of the languages compared. The article shows, that during lexicographical processing of culture elements for a bilingual dictionary, information selected should be defined by cognitive and contrastive principles to estimate knowledge of a dictionary user and help people of two different cultures understand each other.
\end{abstract}

Keywords: A bilingual dictionary, Cultural information, Cognitive and contrastive principles

\section{Introduction}

One of the main problems is dictionaries not satisfying users' requirements. The dictionary traditionally represents an equivalent, grammatical characteristics and examples of the use of words in speech. These dictionaries are called passive as opposed to active.

\section{Literature review}

According to V. G. Gak the main task of a passive dictionary is to reveal word meaning. In a certain context reader can find the necessary translation on his/her own using his/her native language. In an active dictionary a reader doesn't search for explanation of the word to be translated (he/she knows it already) but for instructions helping him/her to find an exact equivalent in the target language (Гак, 1995: 53).

Dictionaries, from our point of view, should include not only linguistic, but also cultural information to perform its function at the present stage of development of science and in terms of modern communication. This point of view is not new.

The theory and practice of teaching a foreign language has long established the need to consider «cultural factor» of a person speaking a foreign language. R. Lado mentioned the need for constant comparison of the language and culture of language learners, and gave examples of the results of such a comparison of the form and content of language (in particular its lexical structure) and the culture using the form, meaning, distribution parameters (Lado, 1964: 85, 87).

The same "cultural factor" must be taken into account by a dictionary authors.

The issue "on amount of cultural "connotation" in a bilingual dictionary" was repeatedly brought up by V. P. Berkov (see, e.g.: Берков, 1975; Берков, 2004). He mentions that all the more or less serious dictionaries include some linguistic and cultural knowledge. But it representation of this knowledge is not systematic. Some evidences of culture should be commented on in the full extend but not only regarding their differences in different cultures (Берков, 1975: 418).

Bilingual dictionaries usually have no comment in their articles. Absence of the information in bilingual dictionaries often does not allow a non-native speaker reader to understand texts in a correct way. Readers in this case have to refer to realia dictionaries (see (Словарь лексики духовной культуры кольских саами, 2013; Богораз, 2011).

\section{Research}

Culture reflection in a bilingual dictionary is absolutely important. Cultural elements that must be present in a bilingual dictionary is a lacuna, i.e. evidence of artifacts, social life, history specific to a certain culture, vocabulary demanding 
cultural commenting because of the denotatum (object). In linguistics words denoting such facts are called culture-specific.

In our research word realia, phrases denoting the facts of nonverbal behaviour are included into the group of such realia (е. g. ни пуха ни пера (literally: neither down, nor a feather, Good luck); не сглазить бы (Knосk on wood!); с первым апреля (April Fools')). We consider nomenclature names (валерьянка (valerian drops), индийский чай (Indian tea), ливерная (liverwurst), докторская колбаса (literally: doctor sausage), cigarettes "Казбек”(Kazbek) and "Беломорканал" (Belomorkanal), shops “Детский мир" (literally: Children World, Detskiy Mir)) and phrases with cultural connotation (десять лет без права переписки (ten years of prison without right to write letters), московские кухни (Moscow kitchens), пятая графа (fifth column)) as a separate group.

There are numerous examples of using cultural information in the dictionary definition in a bilingual lexicography, which indicates that this kind of information is very important. However the classification of the elements of such cultural information hasn't been carried out by now.

Taking into account cultural value of a feature we selected the following elements of a realia description that should be, in our opinion, present in a bilingual dictionary: a) attributes (appearance, components, traditions); b) estimation; c) historical markedness (time of usage, actions); d) social status (functions); e) function (purpose, role); f) popularity / unpopularity of a realia; g) symbolic meaning.

E. g., the equivalent of the Russian word "будёновка" (Budenovka) should be provided with a cultural commentary that describes the appearance of a cap and / or requires to an illustration. Moreover, the Russian realia Budenovka was a headdress of soldiers who served in the Red Army, under the command of the famous military leader Budenniy. How could this information be used? For the Russian user not familiar with the background, it gives information on his/her own culture, to a foreign user - the information about the foreign culture. In the end, it helps communication and understanding of another culture.

Presence of cultural information in a bilingual dictionary is especially significant for languages of indigenous peoples, such as indigenous people of the North, e. g., the Sami (see (Bakula, 2013)). This information not only helps to use correct words for the realia of this 'dying' ethnic group, but also keeps Sami people's culture for future generations. According to the famous researcher of the Lappish Language and Culture G. M. Kert, the Lappish people were separated from their natural environment. The traditional economy being originally Lappish became a state economy and has not brought profit to the Lappish population it could have (Прибалтийско-финское языкознание, 2003).

Analysis of the Sami-Russian dictionaries, published in Russia, showed that the dictionaries include cultural information providing a non-native speaker studying Lappish with an idea of some realia of the Lappish life.

Comments in brackets in such Sami-Russian dictionaries (Афанасьева, 1985; Керт, 1986) have the following meaning: 1. Attributes (appearance, components, traditions); 2. Function (purpose, role); 3. Symbols.

1. Attributes (appearance, components, traditions).

In certain cases a dictionary article provides a detailed comment on the appearance of realia. See: роавв - a blanket from reindeer skin (sewed from woolly reindeer skins with hair inside; the bottom part is a pocket of about $50 \mathrm{~cm}$ where 2 or 3 persons can put their feet; bell-shaped top, body sides are tucked up in it) (Афанасьева, 1985: 293); та̄ссэм - a belt (for men, out of juft or cowhide, $10 \mathrm{~cm}$ wide, clasped by ornamented metal buckles. The celebratory belt is decorated by an ornament from metal or bone; on the left side a sheath is attached with chains to a belt, on the right it has a leather sack for papers, etc.) (Афанасьева, 1985: 346); $m \bar{h} h n$ - a sheath (a case for the hunting knife, usually hollowed out from a whole piece of birch and covered with juft, can be made and of two halves sewed by reindeer tendons; fastened to a leather belt using chains) (Афанасьева, 1985: 355).

More often comments describe the components of realia. See: бурка - felt boots with leather soles (knee-deep, female or children's, made of koyba; decorated on seams with color cloth, the forward part is decorated by ornamented koyba of a contrast color, е. g., ornament with reindeer heads with antlers) (Афанасьева, 1985: 31-32); ва̄ $2 \kappa$ - a pack-saddle, sabretache (a crossbeam with bottom ends fixed by belts under the reindeer abdomen and a load suspended on its top ends) (Афанасьева, 1985: 32); вагкхэсс - a bow-shaped scraper for dressing of small skins (on two perpendicular boards; the horizontal board is used for seating) (Афанасьева, 1985: 33); воал,л, - a long board used for fishing (a tool for ice fishing, a long narrow a board with the pointed end and a hole on other end for net ropes; the board with the net is extended from an ice hole to an ice hole) (Афанасьева, 1985: 48).

In certain cases the information is very important for the life of northern people (вуббресь - a three-year-old male deer (at this age they begin to be trained for team driving; in its middle in particular) (Афанасьева, 1985: 52)), in some case 
a recipe is provided (канн $и$ - a dish prepared of black crowberries with reindeer fat, hot reindeer fat is poured over cold crowberries; each berry is covered by fat) (Афанасьева, 1985: 99)).

Sometimes attributes express the dynamics. Compare: $\bar{a} в в ь л-$ a crossbeam with hooks for suspension of teapots or pots over fire; sometimes a stick with a knot movably joined to the crossbeam by means of a rope loop was used; now metal hooks on chains are used, up to three hooks are suspended over the fire (Афанасьева, 1985: 19).

2. Function (purpose, role).

In the overwhelming majority of cases a function of realia (its purpose, role) depends on the conditions of the people's life. In order to survive in severe conditions it is important to indicate the object's purpose. E. g.: a female reindeer from 4 to 8-10 years; the strongest and wisest becomes the herd leader) (Афанасьева, 1985: 23); вуэгкшэ - with thick fur (e.g., a reindeer) $<\ldots>$ (reindeers slaughtered in winter have thick fur, their fells are used for footwear, blankets, etc.; fells of reindeers slaughtered in autumn are used for overcoat) [2:53]; māбnb - a pole, a pyramid (of about $1.5 \mathrm{~m}$, installed at tops of tundra mountains for orientation) (Афанасьева, 1985: 340).

3. Symbols.

By mentioning symbols of realia in this article we mean an indication of a certain fact known to each native speaker and connected to the role of realia in the culture. Knowledge of this fact helps an individual to feel himself or herself a part of ethnos, defining his/her behavior (in this case language behavior) with the certain standards used within this ethnos, verbal and behavioral cliches.

Status of the realia in the given culture is influenced by several factors such as realia role (e. g., in rituals, ceremonies or in country and people life) and traditions of its understanding (folklore and literature images, clichés, images of everyday life, official/informal symbols of the countries etc.). A symbol always brings a traditional image to the mind of a native speaker, a typical situation connected with religious, mythological and traditional ideas. Therefore the indication of realia symbols in a bilingual dictionary should include the following:

1) indication of religious and mystical symbols;

2) indication of traditional and every day life symbols;

3) indication of political symbols;

Such information will be specific to this country as it represents associations typical for this culture and helps native speakers to understand it.

Different groups of objects can have certain symbols. As it was expected for the analyzed dictionary first of all natural phenomena posess symbols (see: иммель лоанньт - dipper (literally, a divine bird; according to the Lappish beliefs this bird brought to God a blade of grass that produced the Earth) (Афанасьева, 1985: 91)). In certain cases generalizations are the results of centuries-old life experience (see: кйллев - talkative, garrulous; кйллев парна кугкь ев е $л ь$ - children who think like adults don't live a long life (according to the Lappish beliefs that children who grow up intellectually don't live a long life) (Афанасьева, 1985: 109)). We consider references to religious and mythological

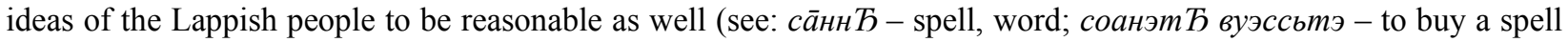
(according to the Lappish beliefs a spell will not be valid unless you pay for it) (Афанасьева, 1985: 315)).

In general we consider the dictionary (Афанасьева, 1985) to be a very successful representation of the realia of Lappish life (realia both as words and concepts). It describes peculiarities of the national material culture, e. g. fur clothes protecting from bitter frosts, much meat as a result of hunting, movable house suitable for nomadic life, fishery, reindeer breeding (see: (Черняков, $1998: 14)$ ).

Comments in the brackets sometimes include fundamentally important cultural information. In our opinion, this information is not supplementary, but essential: лоаййm - a place in a tent of skin and bark for sleeping (lateral side) (Афанасьева, 1985: 162); лўnnс - a place in a tent of skin and bark for food and dishes (in the part opposite to the door) (Афанасьева, 1985: 168). Spatial characteristics (width, depth, ceiling-floor, length) as well as size are important for the Lappish people. We see it in the nomination. E. g.: пуррк - the bottom part of a branched reindeer antler (Афанасьева, 1985: 272); туллльй - a skin (a large animal) (Афанасьева, 1985: 362); куэшшь - a skin of a small animal (Афанасьева, 1985: 138); на̄ $к ь$ - a skin with short sleek fur (Афанасьева, 1985: 205); няввь - long fur on the reindeer neck (Афанасьева, 1985: 224); пижь - a short tail (of a deer, a hare, a sheep, etc.) (Афанасьева, 1985: 255); péjjm - the top part of the net (a thick rope with loops and the net on it) (Афанасьева, 1985: 292); pécc - cell width of the top net row (Афанасьева, 1985: 292); ма̄jjк - a large whitefish (Афанасьева, 1985: 180). 
However, from the lexicographic point of view some comments are not very clear. As such, it is necessary to keep in mind that explanations (comments) are provided for a non-native speaker, i.e. should be focused on the needs of the people of another culture (material and spiritual). Therefore it is not clear, for example, why the comment "untrained reindeers are sent to slaughter" is provided with the word ерррьк - a male reindeer, a stag (from 5 to 12-15 years; untrained reindeer are sent to slaughter) (Афанасьева, 1985: 81). Ethnographical researches of the Lappish people mention that the trained stags were used for any kind activity/work. So tame or island reindeers used for riding with a load pack or in a team (Прибалтийско-финское языкознание 2003: 69) were the most trained stags. A person not aware of the peculiarities of cloudberry ripening (inhabitants of the northern regions of Russia native speakers of Russian are aware of it) faces difficulties in understanding the comment to "чоарэх" (an unripe berry, usually about cloudberries of red color) (Афанасьева, 1985: 398). A cloudberry is a berry, red when unripe, orange and yellow when ripe. However, the comment in brackets to the word "ва̄лльм" (вйлльм - a shoulder (of a reindeer) seems to be important (Афанасьева, 1985: 35).

So, culture information selection in a bilingual dictionary should be defined by 2 principles: during lexicographical processing of culture elements in a bilingual dictionary the information selection should be defined by cognitive and contrastive principles to estimate knowledge of a dictionary user and help people of two different cultures understand each other. In connection to the hypothesis put forward the research objective assumes developing a theory of cultural information representation in a bilingual dictionary.

In this research we consider the cognitive principle as an orientation towards the knowledge of a non-native speaker, $\mathrm{i}$. e. a bilingual translation dictionary is to explain the things that a native speaker knows (really or potentially), but not to explain the things that a dictionary user knows, i. e. non-native speaker.

In this research the contrastive principle of material selection assumes that any information on a realia will contain nationally specific data and their specificity in a bilingual dictionary should be estimated comparing to another language or another culture.

It is obvious that only the features that distinguish the object given or that are very important for the public life should be represented in a bilingual dictionary. Not everything that a native speaker knows about an object or that is associated for him/her with this object is to be given to a non-native speaker.

It is to be emphasized that, for example, definitions of a Russian word in a Russian-German dictionary in many cases will be different comparing to the definition of the same word in a Russian-Polish or a Russian-Vietnamese dictionary.

E. g. Баба-яга (Baba-Yaga) as a character from fairy tales is translated as Baba-Jaga and demands certain comments for Swedish and Norwegian native-speakers similar to the one in Berkov, 1994 ("gammel heks i slavisk mytologi; bortfører og fort o rer barn, flyr i en morter, utvisker sine spor med en kost, bor i urskogen $i$ en «hytte på hønebein" (old witch in Slavic mythology who steals and eat children, flies in a mortar, wipes out her tracks with a broom, lives in a wood in the "izba on chicken legs")). A comment like "trollgumma (häxa) i ryska folksagor (a witch in Russian fairy tales) (Русско-шведский словарь, 1992)" is not sufficient for a Swedish native-speaker. A Swedish native-speaker sees "häxa" (witch) as a woman with supernatural abilities used to do harm to people.

For a Russian native-speaker Баба-яга is: безобразная старуха-колдунья, передвигавшаяся в ступе $u$ заметающая след помелом (хозяйка леса, повелительница его обитателей, вещая старуха, страж входа в царство смерти, живущая в дремучем лесу в избушке на курьих ногах), помощница героя (an ugly old woman-sorceress moving in a mortar and wiping out her tracks with a broom (mistress of wood, sovereign of its inhabitants, prophetic old woman, guard at the entrance to the kingdom of death, living in the dense wood in the izba on chicken's legs), hero's helpmate) (Большой толковый словарь, 2000). Thus in a Russian-Swedish dictionary the translation comment should be to our opinion as follows: an ugly old woman predominating over witches and other evil spirits, lives in a dense wood, in the izba on chicken's legs, turning on her command, flies in a mortar, wipes out her tracks with a broom; luring heroes of fairy tales (especially children) to her izba she roasts them in a stove by throwing them into it with a spade.

Other comments are demanded for a Czech native-speaker. Knowing that Баба-яга is not only a character of Russian fairy tales, but also a hero of slavic mythology we can assume that the comment for Swedish native-speakers will be redundant for a Czech language native-speaker. The only thing that distinguishes the Czech Баба-яга from the Russian one is that she is wicked and never helps heros. So comments to the translation into Czech can be as follows: in Russian fairy tales Баба-яzа is sometimes a hero helpmate, she favours heros and gives them advice. 


\section{Conclusions}

Problems of intercultural communications can be successfully solved if there is a dialogue of representatives of different cultures. Bilingual dictionaries are an effective means of such dialogue. In our opinion, it is essentially important not only to preserve the information on realia, but also give a non-native speaking user of the dictionary a complete idea on it.

\section{References}

Афанасьева Н.Е. (1985). Саамско-русский словарь / Н.Е. Афанасьева, Р.Д. Куруч, Е.И. Мечкина и др.; Под ред. Р.Д. Куруч. М. (Afanas 'eva N.E. Saamsko-russkij slover' / N.E. Afanas 'eva, R.D. Kuruch, T.I. Mechkina i dr.; Pod red. Kuruch R.D. M., 1985).

Берков В.П. (1975). Словарь и культура народа // Мастерство перевода: Сб. 10. М. (Berkov V. P. Slovar' i kul'tura naroda // Masterstvo perevoda: Sb. 10. M., 1975).

Берков В.П. (2004). Двуязычная лексикография: Учебник; 2-е изд., перераб. и доп. M. (Berkov V. P. Dvujazychnaja leksikografija: Uchebnik; 2-e izd., pererab. i dop. M., 2004).

Богораз В.Г. (2011). Луораветланско-русский (чукотско-русский) словарь: 2-е изд. M. (Bogoraz V.G. Luoravetlansko-russkij (chukotsko-russkij) slovar': 2-e izd. M., 2011).

Большой толковый словарь русского языка. (2000). / Сост. и гл. ред. С. А. Кузнецов. СПб. (Bol'shoj tolkovyj slovar' / Sost. i gl.red. S.A. Kuztetsov. СПб., 2000).

Гак В.Г. (1995). Двуязычный словарь активного типа // Язык - система. Язык - текст. Язык - способность: Сб. ст. М. (Gak V. G. Dvujazychnyj slovar' aktivnogo tipa // Jazyk — sistema. Jazyk — tekst. Jazyk sposobnost': Sb. st. M., 1995).

Словарь лексики духовной культуры кольских саами. (2013). / авт.-сост. О.Н. Иванищева, В.Б. Бакула. Мурманск. (Slovar' leksiki duhovnoj kultury kol'skih saami/ avt.-sost. O.N. Ivanishcheva, V.B. Bakula. Мурманск, 2013).

Керт Г.М. (1986). Словарь саамско-русский и русско-саамский: пособие для уч-ся нач. шк. / Г.М. Керт. Л. (Kert G.M. Slovar ' saamsko-russkij i russko-saamskij: posobije dl'a uch-s'a nach.shk. Л., 1986).

Прибалтийско-финское языкознание. (2003). Петрозаводск. (Pribaltijsko-finskoje jasykosnanije. Петрозаводск, 2003).

Русско-шведский словарь. (1992). / Под ред. К. Давидссон. Stockholm. (Russko-shvedskij slovar' / Pod red. K. Davidsson. Stockholm, 1992).

Черняков 3.Е. (1998). Очерки этнографии саамов. Рованиеми. (Chernyakov Z. E. Ocherki etnografii saamov. Рованиеми, University of Lapland, 1998).

Bakula V.B. (2013). Sami writers of the Kola peninsula L Image du Sápmi II. ÖREBRO UNIVERSITY. Pp. 444-459.

Berkov V. (1994). Russisk-norsk ordbok: 2. utgave. Oslo.

Lado R. (1964). Linguistics across Cultures: Applied Linguistics for Language Teachers. [S. 1.], 1964. 